\title{
Morphology and surface features of olivine in kimberlite: implications for ascent processes
}

\author{
T. J. Jones ${ }^{1,2}$, J. K. Russell ${ }^{1}$, L. A. Porritt ${ }^{1,2}$, and R. J. Brown ${ }^{3}$ \\ ${ }^{1}$ Department of Earth, Ocean and Atmospheric Sciences, University of British Columbia, Vancouver, V6T 1 Z4, Canada \\ ${ }^{2}$ School of Earth Sciences, University of Bristol, Wills Memorial Building, Bristol, BS8 1RJ, UK \\ ${ }^{3}$ Department of Earth Sciences, Science Labs, Durham University, Durham, DH1 3LE, UK \\ Correspondence to: T. J. Jones (thomas.jones.2010@my.bristol.ac.uk)
}

\begin{abstract}
Most kimberlite rocks contain large proportions of ellipsoidal-shaped xenocrystic olivine grains that are derived mainly from disaggregation of peridotite. Here, we describe the shapes, sizes and surfaces of olivine grains recovered from kimberlite lavas erupted from the Quaternary Igwisi Hills volcano, Tanzania. The Igwisi Hills kimberlitic olivine grains are compared to phenocrystic olivine, liberated from picritic lavas, and mantle olivine, liberated from a fresh peridotite xenolith. Image analysis, scanning electron microscopy imagery and laser microscopy reveal significant differences in the morphologies and surface features of the three crystal populations. The kimberlitic olivine grains form smooth, rounded to ellipsoidal shapes and have rough flaky micro-surfaces that are populated by impact pits. Mantle olivine grains are characterised by flaked surfaces and indented shapes consistent with growth as a crystal aggregate. Phenocrystic olivine exhibit faceted, smooth-surfaced crystal faces. We suggest that the unique shape and surface properties of the Igwisi Hills kimberlitic olivine grains are products of the transport processes attending kimberlite ascent from mantle source to surface. We infer that the unique shapes and surfaces of kimberlitic olivine grains result from three distinct mechanical processes attending their rapid transport through the thick cratonic mantle lithosphere: (1) penetrative flaking from micro-tensile failure induced by rapid decompression; (2) sustained abrasion and attrition driven by particle-particle collisions between grains within a turbulent, volatile-rich flow regime; and (3) higher-energy particle-particle collisions producing impact cavities superimposed on decompression structures. The combination of these processes during the rapid ascent of kimberlite magmas is responsible for the distinctive ellipsoidal shape of olivine xenocrysts found in kimberlites worldwide.
\end{abstract}

\section{Introduction}

Kimberlite magmas, derived from low degrees of partial melting of the mantle, erode, carry and erupt significant amounts of crystalline lithospheric mantle as whole rock xenoliths and as single crystals or xenocrysts (e.g. Mitchell, 1986). They are consequently important geochemical and physical windows into the inner Earth. Abundant, subrounded to rounded, ovoid to elliptical grains of xenocrystic mantle olivine are characteristic of kimberlite intrusions, lavas and pyroclastic rocks (e.g. Brett et al., 2009; Clement and Skinner, 1979, 1985; Dawson and Hawthorne, 1973; Gernon et al., 2012; Kamenetsky et al., 2008; Mitchell, 1986, 2008; Moss and Russell, 2011).

However, the origin of their ellipsoidal morphologies remains somewhat enigmatic given that they represent disaggregated crystalline rocks. Explanations include rounding by magmatic corrosion and dissolution of the grains during ascent (Kamenetsky et al., 2008; Mitchell, 1986; Moore, 2012; Pilbeam et al., 2013) or mechanical milling (Arndt et al., 2006, 2010; Brett et al., 2009; Brett, 2009; Kamenetsky et al., 2008; Reid et al., 1975; Russell et al., 2012). Rapid $\mathrm{CO}_{2}$ release following digestion of orthopyroxene was recently proposed as a mechanism for propelling kimberlite magmas rapidly to the surface over short timescales (Russell et al., 2012). Such a process is potentially a significant factor in increasing the erosive potential of the ascending magmas at depth. Intuitively, chemical corrosion and milling should leave different physical signatures on the exteriors of mantle-derived crystals, which, if not overprinted by latestage crystal growth rims, or removed by alteration, should be discernible with scanning electron microscopy (SEM). Such features can provide insights into the nature of kimberlite magma transport from the mantle upwards: a topic 
still relatively poorly understood (e.g. Russell et al., 2012; Sparks, 2013; Sparks et al., 2006).

Here, we semi-quantitatively describe and analyse the shapes and surfaces of fresh xenocrystic olivine extracted from a Quaternary kimberlite lava in Tanzania. Our goals are two-fold: firstly, to understand the processes that create the highly distinctive shapes and surfaces of olivine crystals characteristic of kimberlite rocks and, secondly, to constrain ideas on the ascent of kimberlite magma.

\section{Olivine in kimberlite}

This study focusses on the physical and morphological features present on the surfaces of kimberlitic olivine. Our work builds on an extensive literature of petrographic and geochemical studies of kimberlitic olivine (Table 1) aimed at constraining the origins of kimberlite magmas (e.g. Arndt et al., 2006; Table 1; Arndt et al., 2010; Brett et al., 2009; Dawson, 1994; Kamenetsky et al., 2008; Mitchell, 1970, 1986, 1995, 2012; Pilbeam et al., 2013). The large number of detailed studies of olivine in kimberlite reflects the pervasively high abundance of olivine in these enigmatic rocks.

Mitchell (1986) separated olivine within kimberlite into phenocrystic and xenocrystic populations. Xenocrystic olivine, termed "macrocrysts", are rounded in shape and the most abundant volumetrically. "Phenocrystic" olivine was distinguished in the groundmass on the basis of a finer-grain size $(<0.5 \mathrm{~mm})$ and its (sub-)euhedral character. However, in recent years, many workers have ascribed a xenocrystic origin to both olivine populations. Both populations are observed to have xenocrystic cores and magmatic rims (e.g. Arndt et al., 2010; Brett et al., 2009). Work by Arndt et al. (2010) has suggested mechanical abrasion as a process which operates during ascent. They observe rounded centimetre-scale aggregates of olivine, described as monomineralic dunitic nodules. The olivine is typically deformed, has variable composition, and has more Fe-rich rims and is therefore interpreted to be xenocrystic in origin. Arndt et al. (2010) suggested that kimberlite melts sampled and entrained fragments of a "defertilised", largely dunitic, mantle lithosphere. The mantle-derived dunitic xenoliths become disaggregated during ascent, and olivine crystallises as rims on the mantle olivine and as euhedral crystals during ascent. They noted that the late rims on xenocrystic olivines could be chemically heterogeneous and commonly absent on protruding portions of the rounded nodule. This is attributed to abrasion processes on ascent (Arndt et al., 2006, 2010).

Kamenetsky et al. (2008) argued for transport in an initially chloride-carbonate melt causing mechanical abrasion and chemical resorption of xenocrystic olivine and orthopyroxene before reaching olivine saturation and crystallisation. They ascribed a xenocrystic origin to both olivine populations (macrocrysts and phenocrysts), which they referred to as type 1 and 2, respectively. They also argued that, dur- ing emplacement, the kimberlite reaches olivine saturation and crystallises rims on the xenocrystic olivine and minor groundmass phases (Kamenetsky et al., 2008).

Brett et al. (2009) used textural evidence combined with electron microprobe analysis of $\mathrm{Ni}$ contents in olivine to document the xenocrystic origins of kimberlitic olivine, regardless of grain size or shape. Their work corroborates the reported chemical trends observed in olivine from the Igwisi Hills kimberlite (Fig. 8; Dawson, 1994). Brett et al. (2009) demonstrate small volumes $(\leq 5 \%)$ of heterogeneous olivine crystallisation from the kimberlitic melt during ascent. This occurs on cores of pre-existing rounded xenocrystic olivines (at all sizes). The crystallisation is caused by orthopyroxene dissolution which drives the melt towards olivine saturation. The small volume of crystallisation only affects the overall shapes of the smallest xenocrysts to create the euhedral (apparent) "phenocryst" population of olivine grains.

Other studies have proposed a complex interplay between reabsorption and crystallisation during kimberlitic ascent (Moore, 2012). In Moore's model, rounding is caused by melt resorption, predicted to occur at multiple times and linked to superheating events during ascent. Pilbeam et al. (2013) also suggest resorption processes during ascent. Here, the digestion of a xenocrystic cargo coupled with the fractional crystallisation is thought to explain the marginal profiles on olivine. During reactive transport magmatic rims are crystallised on xenocrystic cores (Pilbeam et al., 2013).

Our study here aims to explore the evidence for mechanical processes which operate on olivine crystal cargo (i.e. xenocrysts) during kimberlite ascent. Our results, in part, answer some of the questions concerning the mechanisms of kimberlite ascent and reconcile some of the disparate observations and ideas found in the literature (Table 1).

\section{Igwisi Hills volcanoes}

The Quaternary Igwisi Hills monogenetic volcanoes (IHV), Tanzania, erupted a minimum of $3.4 \times 10^{7} \mathrm{~m}^{3}$ of kimberlite magma. The eruptions produced three small volcanic edifices located along a $\sim 2 \mathrm{~km} \mathrm{NE}-\mathrm{SW}$-trending fissure (Fig. 1): the NE, SW and central volcano (Brown et al., 2012). The $\sim 10 \mathrm{ka}$ IHV are the youngest kimberlite volcanoes on Earth - postdating the next youngest kimberlite volcanoes by $\sim 30 \mathrm{Ma}$ (Brown et al., 2012). The Igwisi Hills volcanic deposits represent one of very few occurrences of fresh kimberlites showing remarkably low degrees of alteration/minimal serpentinisation (Brown et al., 2012).

Brown et al. (2012) proposed three eruptive phases for the IHV: an initial phreatomagmatic explosive phase of eruption, followed by weak explosive eruptions columns, and then effusion of lava. Brown et al. (2012) estimated that the lavas had high effective viscosities at emplacement $\left(>10^{2}\right.$ to $10^{6} \mathrm{~Pa} \mathrm{~s}$ ) relative to the range commonly ascribed to kimberlite magmas: $\sim 1$ Pa s (e.g. Sparks et al., 2006). The higher 
Table 1. Results from published studies of kimberlite-hosted olivine. The observations and interpretations reported below are filtered for their relevance to the kimberlitic ascent processes elucidated in our study.

\begin{tabular}{|c|c|c|c|}
\hline Source & Observations & Interpretations & Link to kimberlitic processes \\
\hline $\begin{array}{l}\text { Mitchell (1970, } \\
\text { 1986, 1995) }\end{array}$ & $\begin{array}{l}\text { - Macrocrysts: large sub-angular to sub-rounded grains; single crys- } \\
\text { tals or polycrystalline aggregates; } \pm \text { undulose extinction. } \\
\text { - Non-macrocrysts: }<0.5 \mathrm{~mm} \text { (sub-)euhedral unstrained, olivine } \\
\text { grains with planar crystal faces. }\end{array}$ & $\begin{array}{l}\text { - Larger-sized grains are xenocrystic. } \\
\text { - Smaller-sized grains are "phenocrystic" and crystallised } \\
\text { from kimberlite melt. }\end{array}$ & $\begin{array}{l}\text { - Entrainment and break-up of mantle } \\
\text { peridotite } \\
\text { - Deep-seated crystallisation of olivine } \\
\text { during transport. }\end{array}$ \\
\hline Dawson (1994) & $\begin{array}{l}\text { - Large xenocrystic olivines }\left(\sim \mathrm{Fo}_{92}\right) \text { compositionally similar to } \\
\text { olivine in peridotitic mantle xenoliths. } \\
\text { - Large olivines are zoned and rims show } \mathrm{CaO} \text { and } \mathrm{MnO} \text { enrichment } \\
\text { and } \mathrm{NiO} \text { depletion. } \\
\text { - Cores of "matrix" olivines are distinct from xenocrystic olivine (i.e. } \\
\text { higher } \mathrm{Fe}, \mathrm{Ca}, \mathrm{Ti}) \text {. } \\
\text { - Elongate matrix grains can show } \mathrm{CaO} \text { zoning with } \mathrm{CaO} \text { contents } \\
\text { similar to neoblasts found on margins of xenoliths. }\end{array}$ & $\begin{array}{l}\text { - Large xenocrystic olivines derive from a well-equilibrated } \\
\text { phlogopite-calcite-garnet lherzolite protolith. } \\
\text { - Some elongate matrix olivines might be rim fragments } \\
\text { (xenocrysts) from the recrystallised margins of xenoliths. } \\
\text { - Sits on the fence - it is also stated that some of the smaller } \\
\text { olivines may have crystallised from the kimberlite magma. }\end{array}$ & $\begin{array}{l}\text { - Entrainment and break-up of man- } \\
\text { tle peridotite producing xenocrystic } \\
\text { olivine } \\
\text { - Matrix olivine include neoblasts from } \\
\text { peridotite and possible olivine crys- } \\
\text { tallised from kimberlite. }\end{array}$ \\
\hline $\begin{array}{l}\text { Arndt et al. } \\
\text { (2006) }\end{array}$ & $\begin{array}{l}\text { - Rounded centimetre-scale aggregates of olivine ( } 5-45 \text { vol. \%) de- } \\
\text { scribed as nodules. } \\
\text { - Fo compositions are constant within a nodule but vary greatly (Fo } \\
\text { 81-93) between nodules. } \\
\text { - Olivine in nodules and matrix record deformation. } \\
\text { - Many nodules have thin rims of high Ca. }\end{array}$ & $\begin{array}{l}\text { - Mechanical abrasion produced rounded nature of each nod- } \\
\text { ule. } \\
\text { - Both olivine in nodules and matrix are xenocrystic in ori- } \\
\text { gin. } \\
\text { - Marginal rims represent crystallisation from the kimberlite } \\
\text { melt. }\end{array}$ & $\begin{array}{l}\text { - Mantle "defertilisation" removes all } \\
\text { minerals but olivine from lithospheric } \\
\text { mantle peridotite. } \\
\text { - Defertilisation creates dunitic source } \\
\text { and presages kimberlite magmatism. } \\
\text { - Magma entrains and rounds dunitic } \\
\text { mantle nodules. }\end{array}$ \\
\hline $\begin{array}{l}\text { Kamenetsky et } \\
\text { al. (2008) }\end{array}$ & $\begin{array}{l}\text { - Trace element abundances, oxygen isotopes ratios and } \mathrm{Mg} \text { con- } \\
\text { tents of olivine-I (macrocrysts) and cores of olivine-II ("ground- } \\
\text { mass olivine") are indistinguishable. }\end{array}$ & $\begin{array}{l}\text { - Incorporation of peridotitic olivine (I). } \\
\text { - Early crystallisation of olivine (II) at depth in small melt } \\
\text { pockets. } \\
\text { - Both olivine populations transported to surface within a } \\
\text { chloride-carbonate melt } \\
\text { - Additional low-pressure crystallisation of olivine rims. }\end{array}$ & $\begin{array}{l}\text { - During transport mantle olivine and } \\
\text { orthopyroxene are partially abraded, } \\
\text { chemically reabsorbed, and recrys- } \\
\text { tallised. } \\
\text { - Olivine crystallises from kimberlite } \\
\text { melt as rims on larger grains of olivine. }\end{array}$ \\
\hline $\begin{array}{l}\text { Brett et al. } \\
(2009)\end{array}$ & $\begin{array}{l}\text { - Disparities in Ni contents between rims and cores of two olivine } \\
\text { size populations. Lower Ni within the rim. } \\
\text { - Textural zonation of rims on rounded high-Ni cores defined by } \\
\text { fluid/mineral inclusions. }\end{array}$ & $\begin{array}{l}\text { - Macrocrysts and cores of smaller olivine grains are } \\
\text { xenocrystic. } \\
\text { - Rims of macrocrysts and smaller grains result from mag- } \\
\text { matic crystallisation of the kimberlitic melt. } \\
\text { - The rims are thin; they do not change the shape of the previ- } \\
\text { ously rounded grains but trap mineral and fluid inclusions. }\end{array}$ & $\begin{array}{l}\text { - Late, small-volume }(\leq 5 \%) \text { heteroge- } \\
\text { neous crystallisation of phenocrystic } \\
\text { olivine from kimberlitic melt during as- } \\
\text { cent. } \\
\text { - Coupled orthopyroxene dissolution and } \\
\text { olivine crystallisation during ascent. } \\
\text { - For larger }(\sim 25 \text { vol. } \%) \text { amounts of } \\
\text { orthopyroxene assimilation, kimberlite } \\
\text { needs to be superliquidus }\left(\geq 100^{\circ} \mathrm{C}\right) \text {. }\end{array}$ \\
\hline $\begin{array}{l}\text { Arndt et al. } \\
\text { (2010) }\end{array}$ & $\begin{array}{l}\text { - Describes centimetre-scale monomineralic olivine nodules } \\
\text { - Nodules have variable Fo compositions but lower-Fo rims. } \\
\text { - Olivine rims have high } \mathrm{CaO} \text { and } \mathrm{MnO} \text { but low } \mathrm{NiO} \text {. } \\
\text { - Commonly chemical rims are absent on protruding portions of the } \\
\text { nodule. } \\
\text { - Nodule mineralogy and abundance suggest a non-garnet-peridotite } \\
\text { source. }\end{array}$ & $\begin{array}{l}\text { - Xenocrystic olivine is derived mainly from dunitic source. } \\
\text { - Lower Fo-rich rims crystallised on ascent. } \\
\text { - Euhedral grains re-crystallised on ascent. } \\
\text { - Rounding of nodules by mechanical abrasion occurs during } \\
\text { ascent, after liberation, and locally removes chemical rims. }\end{array}$ & $\begin{array}{l}\text { - Mantle de-fertilisation (see above) cre- } \\
\text { ates a dunite lithospheric mantle source } \\
\text { rock. } \\
\text { - Kimberlite magmatism is associated } \\
\text { with deformation of surrounding dunite } \\
\text { and peridotite. } \\
\text { - Fluid pressure increases in the pocket } \\
\text { and fractures overlying mantle. Flow } \\
\text { then entrains surrounding dunite and } \\
\text { normal peridotite higher up. }\end{array}$ \\
\hline Moore (2012) & $\begin{array}{l}\text { - Cores and edges of most olivines cover a continuous compositional } \\
\text { field. There is an overlap in chemical composition between the core } \\
\text { and the rim in most Group } 1 \text { and Group } 2 \text { kimberlites. } \\
\text { - The morphology of small "groundmass" olivine is comparable to } \\
\text { those crystallised from a moderately under-cooled melt. }\end{array}$ & $\begin{array}{l}\text { - Rounding result from chemical; resorption into melt. } \\
\text { - Resorption of olivine linked to repeated superheating } \\
\text { events during ascent. } \\
\text { - Exsolution at shallow depths causes fluidisation and loss of } \\
\mathrm{CO}_{2} \text {. } \\
\text { - Cooling due to } \mathrm{CO}_{2} \text { loss triggers late-stage (groundmass } \\
\text { and rims) olivine crystallisation. }\end{array}$ & $\begin{array}{l}\text { - All olivine results from polybaric crys- } \\
\text { tallisation of kimberlite melt during as- } \\
\text { cent and involving interplay between } \\
\text { supersaturation and dissolution. }\end{array}$ \\
\hline $\begin{array}{l}\text { Pilbeam et al. } \\
\text { (2013) }\end{array}$ & $\begin{array}{l}\text { - Olivine cores have variable composition and are determined to be } \\
\text { xenocrystic. } \\
\text { - Over } 90 \% \text { of the olivine grains analysed show normal zoning. } \\
\text { (high-Mg and high-Ni cores) } \\
\text { - Measured core, margin, rim profiles are compared to model profiles } \\
\text { for (1) equilibrium crystallisation, (2) fractional crystallisation, (3) } \\
\text { digestion fractional crystallisation (DFC). } \\
\text { - Observed profiles are best matched to DFC, modelling of minor } \\
\text { diffusion post-DFC removes slight discrepancies. }\end{array}$ & $\begin{array}{l}\text { - Fractional crystallisation coupled with digestion of } \\
\text { xenocrysts (DFC), primarily orthopyroxene, explains ob- } \\
\text { served chemical zoning of } \mathrm{Mg}, \mathrm{Ni}, \mathrm{Ca} \text {, and Mn in olivine. } \\
\text { - This is then followed by minor diffusive re-equilibration. }\end{array}$ & $\begin{array}{l}\text { - Crystallisation of cognate phases oc- } \\
\text { curs during ascent alongside the diges- } \\
\text { tion of a xenocrystic cargo. } \\
\text { - Melt evolves via orthopyroxene disso- } \\
\text { lution. } \\
\text { - Magma emplaced as a slurry of } \\
\text { xenocrystic olivine grains with mag- } \\
\text { matic margins. } \\
\text { - Other xenocrysts and nodule types } \\
\text { transported in a silica-calcium- } \\
\text { carbonatite melt. }\end{array}$ \\
\hline
\end{tabular}




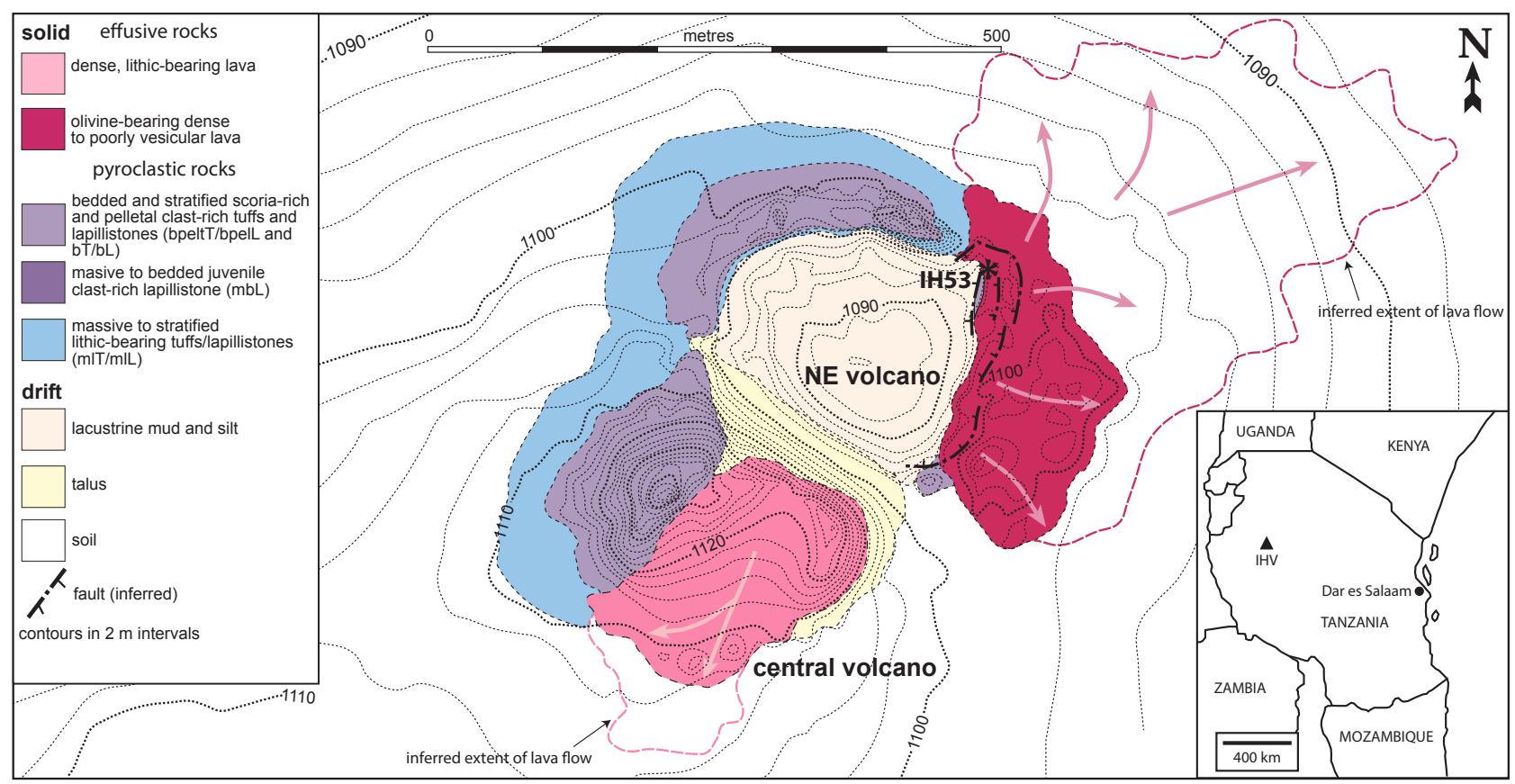

Figure 1. Map of Igwisi Hills volcanoes (IHV), showing the relative positions of the two northernmost volcanic edifices and the location of the lava (IH53) sampled in this study. The Igwisi Hills volcanoes are situated at latitude $4^{\circ} 51^{\prime}$ S, longitude $31^{\circ} 55^{\prime}$ E. Adapted from Brown et al. (2012).

effective viscosities are interpreted as resulting from the effects of shallow magma degassing and partial crystallisation of the groundmass. Brown et al. (2012) also provided a lower limit on magma viscosity by modelling olivine settling, which suggested a partially crystallised Bingham-like fluid with a yield strength and viscosities of $10^{3} \mathrm{~Pa}$.

Dawson (1994) showed that the IHV showed strong affinities to low-alkali, calcite-rich kimberlites such as the Benfontein sills, South Africa. Reid et al. (1975) noted that the Igwisi material is characterised by ellipsoidal forsterite olivine hosted in a fine-grained carbonate-apatite-spinelpervoskite-serpentine matrix. These xenocrysts and the polycrystalline xenoliths are ovoid and range up to $3 \mathrm{~cm}$ (i.e. "micro-xenoliths" in Dawson, 1994; "nodules" in Arndt et al., 2010). In a few cases olivine ellipsoids are rimmed or partially rimmed by pervoskite and $\mathrm{Mg}-\mathrm{Al}$ spinel. Some olivine contains mineral inclusions, including chrome pyrope, $\mathrm{Mg}$ Al chromite, low-Al enstatite, low-Al-Mg-Cr-diopside and high-Mg phlogopite (Reid et al., 1975). Mantle phases present in the micro-xenoliths provide estimates for pressure and temperature at formation. Under the assumption that the clinopyroxene coexisted with low-Ca pyroxene, thermobarometry places the source temperatures at $\sim 1000^{\circ} \mathrm{C}$ (Davis and Boyd, 1966). Additionally, assuming chemical equilibrium, the coexistence of low- $\mathrm{Al}_{2} \mathrm{O}_{3}$ enstatite with pyrope results in pressures of 50-60 kbar (Boyd, 1970).

\section{Sample suite}

In this study three sample sets were analysed. Fifteen individual olivine crystals from the Igwisi Hills (IH) lava are compared with olivine phenocrysts from an Icelandic lava and olivine grains disaggregated from mantle xenoliths. Phenocrysts from the Icelandic lava illustrate surface textures of crystals crystallising from magma stored in the crust, whilst olivine grains disaggregated from mantle peridotitic xenoliths serve as a proxy for the original material prior to kimberlite ascent. We used olivine from an IH lava rather than from the pyroclastic deposits to ensure that the surface textures represented magma transport processes and were not modified by explosive eruption processes. The secondary influence of sub-aerial eruption mechanisms, like secondary fragmentation, can therefore be ignored. Previous studies of the IH kimberlite deposits have also shown that the lavas record minimal alteration (Brown et al., 2012).

\subsection{Phenocrystic olivine}

The picritic lava flow from Iceland contains abundant (>20\%) sub-hedral to euhedral forsteritic olivine phenocrysts with a grain size of approximately $2.5 \mathrm{~mm}$. The sample was coarsely crushed to $\sim 0.4-0.8 \mathrm{~cm}$, and then olivine grains were hand-picked under a binocular microscope. This allowed the crystals to be selected individually to avoid grains with unnatural breakage surfaces. 


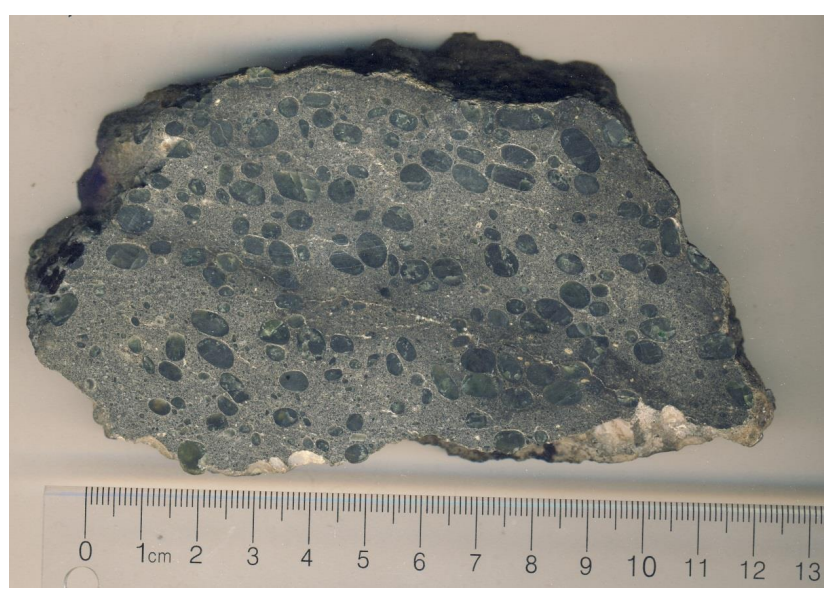

Figure 2. Xenocrystic olivine grains within Igwisi Hills lava sample IH53. High-resolution scan of polished slab of lava sample showing abundance, distribution and highly ellipsoidal shapes of xenocrystic olivine.

\subsection{Mantle olivine}

These samples comprise pristine lithospheric mantle-derived peridotitic xenoliths collected from a basanitic dike from Mt Preston, western British Columbia (BC), Canada (Peterson, 2010). Detailed study of their mineralogy and textures shows that they record mantle equilibration conditions and have not been modified texturally or chemically during or postemplacement (Peterson, 2010). As such, they provide a suitable reference material for the morphology of unadulterated mantle olivine. The peridotite xenolith chosen was friable enough to disaggregate by hand. Olivine grains, $2-4 \mathrm{~mm}$ in diameter, were handpicked under a binocular microscope.

\subsection{Igwisi Hills volcanoes}

Large (1-10 mm) spheroidal olivine crystals make up a large proportion $(\sim 26 \mathrm{vol} . \%)$ of the lower parts of a pāhoehoetype lava flow from the NE volcano at Igwisi Hills (Fig. 2; Brown et al., 2012). Such a high concentration of olivine can be partially attributed to post-emplacement crystal settling and accumulation. The olivine grains are rounded to sub-rounded in shape and have aspect ratios of $\sim 1.5$. The olivine grains were carefully removed by cutting out a small volume of lava with the olivine enclosed by a thin layer of groundmass. The fine groundmass readily disaggregated on rinsing with water. The mineral surface was then checked for any residual attached groundmass using energy-dispersive Xray spectroscopy (EDS) prior to textural analysis. This ensured any dissolution, mechanical or etching features observed were solely the result of the volcanic or magmatic processes rather than the experimental extraction method.

Dawson (1994) measured the compositions of olivine in the IHV lavas by electron microprobe and showed them to be $\sim$ Fo92, compositionally similar to olivine within peri-

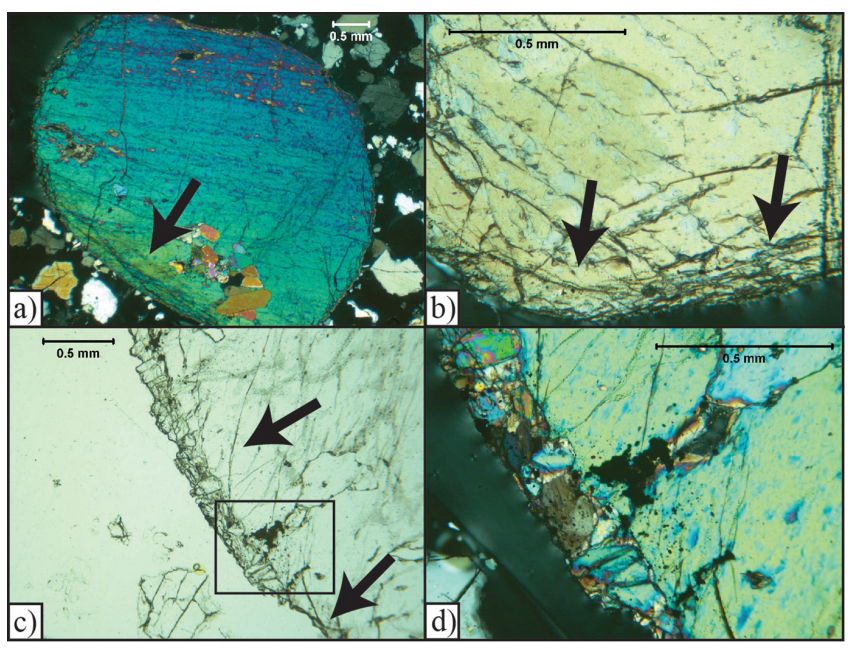

Figure 3. Photomicrographs of grains of olivine separated from sample of Igwisi Hills kimberlite. (a) Photomicrograph under cross-polarised light of a single xenocrystic olivine ellipsoid hosting smaller internal domains of recrystallised olivine. Olivine grain shows pronounced fractures parallel to the grain boundary. (b) High magnification view of olivine grain boundary recording brittle deformation manifest as arcuate fractures along the rim $(<0.1 \mathrm{~mm})$ and at low angles to the grain boundary. (c) Grain boundary showing fine crystals grown along the rim of the larger olivine ellipsoid creating an irregular boundary. Fractures within the main crystal appear to bend towards the finer crystal rim and terminate within it. Again the fine-grained rim is not continuous (absent from the bottom of the photo). (d) Cross-polarised view of box in panel (c) highlighting the fine-grained crystal rim. Arrows in all figures point to the pronounced curved fractures.

dotitic mantle xenoliths. Reid et al. (1975) also measured olivine compositions in the IH volcanic rocks and, similarly, reported a narrow range (Fo90-92). Several larger olivine grains contain small $(<1 \mathrm{~mm})$ inclusions of spinel, clinopyroxene, garnet and/or apatite. These previous studies have also analysed the compositions of rims to the xenocrystic olivine grains from the IH lavas. Reid et al. (1975) and Dawson (1994) measure and describe the chemical zonation in IHV olivines as the rims being enriched in $\mathrm{FeO}, \mathrm{CaO}$ and $\mathrm{MnO}$ and depleted in $\mathrm{NiO}$, relative to their cores (Table 1).

Current ongoing work on the Igwisi Hills lavas sub-divides the olivine macrocrysts population into three groups: (1a) rounded, polycrystalline micro-xenoliths with inclusions of mantle minerals; (1b) Ni-rich, Ca-poor cores with overgrowth rims rich in $\mathrm{CaO}$ and $\mathrm{MnO}$ but poor in $\mathrm{NiO}$; (2) unstrained $<300 \mu \mathrm{m}$ phenocrysts which are chemically homogeneous; and (3) inclusions and intergrowths of olivine within a titanomagnetite host (Willcox et al., 2014). The olivine analysed in this study have been classified as type 1.

Thin section observations on olivine grains show intense fracturing localised on the rims (Fig. 3a and b). Transverse cracks across the individual olivine grains typically bend to- 
wards the heavily fractured/recrystallised rim and terminate within it, not at the edge of the ellipsoid (Fig. 3b). Fractures are commonly filled with opaque mineral inclusions resembling healed/sealed tension cracks (Brett, 2009). The margins of some of the larger rounded olivine grains comprise a randomly oriented aggregate of smaller, $\sim 0.2 \mathrm{~mm}$ sub-grains. These grains (i.e. neoblasts) are the products of recrystallisation of the original strained olivine crystal. The neoblasts replace the original strained olivine grain but preserve the original overall rounded shape, indicating that recrystallisation post-dates or occurs concurrently to the rounding process. Replacement by these strain-free elongate neoblasts is commonly focussed at the grain boundary but is rarely continuous along the rim (Fig. $3 \mathrm{c}$ and d).

The groundmass of the host lava is very fine grained and, although difficult to resolve under a petrographic microscope, comprises carbonate $(40$ vol. $\%)$, small $\sim 1 \mathrm{~mm}$ rounded olivine grains, spinel and perovskite.

\section{Methodology}

\subsection{Image analysis}

Olivine is the dominant phase in kimberlite, and therefore its abundance and grain size distributions are commonly used to characterise kimberlite units (e.g. Field et al., 2009; Jerram et al., 2009; Moss et al., 2010). The corresponding large olivine ellipsoid grain size distribution for the IHV lava is shown in Fig. 4b. The grain size and shape distributions of olivine are based on a high-resolution (1200 dpi) scan of a polished slab (Fig. 2). The resulting digital image was manually traced using Adobe Illustrator ${ }^{\mathrm{TM}}$ to provide a representation of the slab outline and each olivine grain. Olivine grains in the IHV rocks vary from 1 to $10 \mathrm{~mm}$ in diameter. Manual tracing captured all olivine grains with long axes $<1.6 \mathrm{~mm}$. The digital representation of the olivine grains within the slab (Fig. 4a) was analysed using ImageJ software (http://rsbweb.nih.gov/ij/) for geometric parameters including circularity, axis length and area.

\subsection{Scanning electron microscopy}

Hand-picked olivine grains from all three sample sets were mounted, carbon-coated and studied under the Philips XL30 scanning electron microscope (SEM) at the University of British Columbia to document surface textures observed across all sample suites.

\subsection{3-D Laser measuring microscopy}

An Olympus LEXT 3-D Measuring Laser Microscope OLS4000 was used at the Advanced Materials and Process Engineering Laboratory (AMPEL), University of British Columbia, to collect data on the surface topography of the olivine grains. This device is calibrated in the same way as
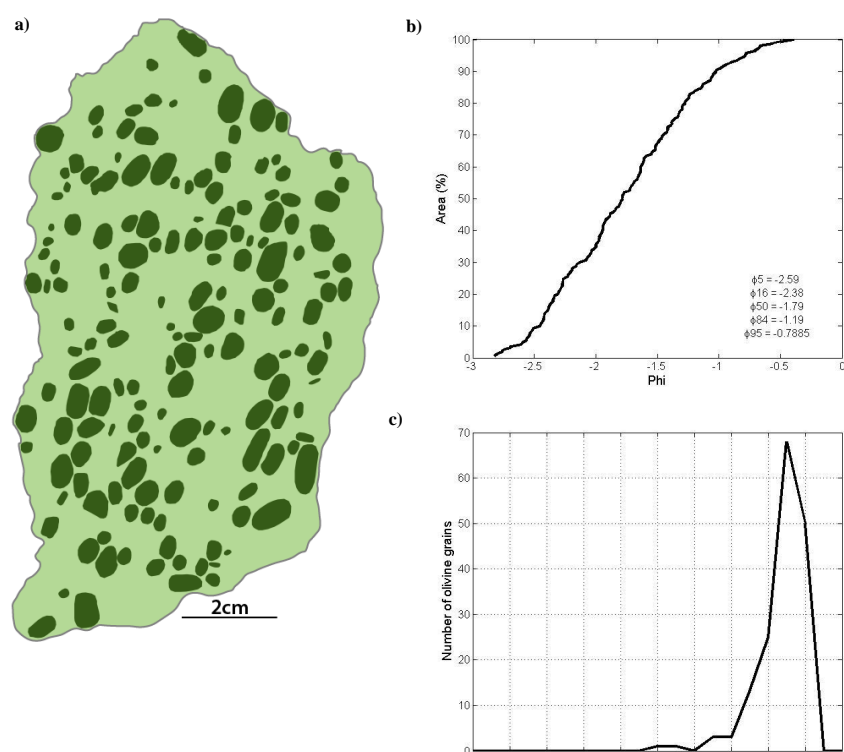

c)

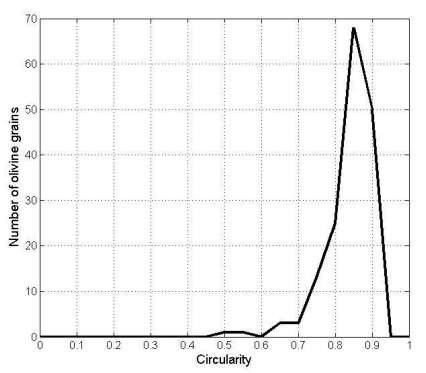

d)

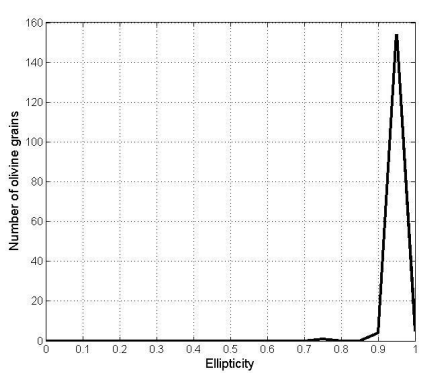

Figure 4. Grain size analysis of olivine grains in the IH53 lava. (a) False-colour digitised image of polished slab of IH53 lava; olivine are coloured dark green. Total slab area is $7138 \mathrm{~mm}^{2}$ and comprises $\sim 27 \%$ xenocrystic olivine. (b) Histogram showing the olivine percentage area as a function of grain size. The grain size is expressed as $\varphi=-\log _{2}(\mathbf{d})$, where $\mathrm{d}$ is the olivine diameter. (c) Frequency distribution curve of circularity $(C)$ of olivine grains defined as $C=(\text { Perimeter })^{2} /(4 \pi *$ Area $) . C=1$ for a perfect circle, and values $0<\mathrm{C}<1$ provide a relative quantification of roundness. (d) A distribution curve, showing the number of olivine grains having a specific ellipticity.

standard stylus instruments for surface measurements; however, it uses contactless measurement with an automatic linestitching function to create a topographic map at a high resolution. These data sets were used to create models for the micron-scale topographic features of olivines from each of the three sample suites. The models were then used to make a quantitative comparison of the surface properties. 

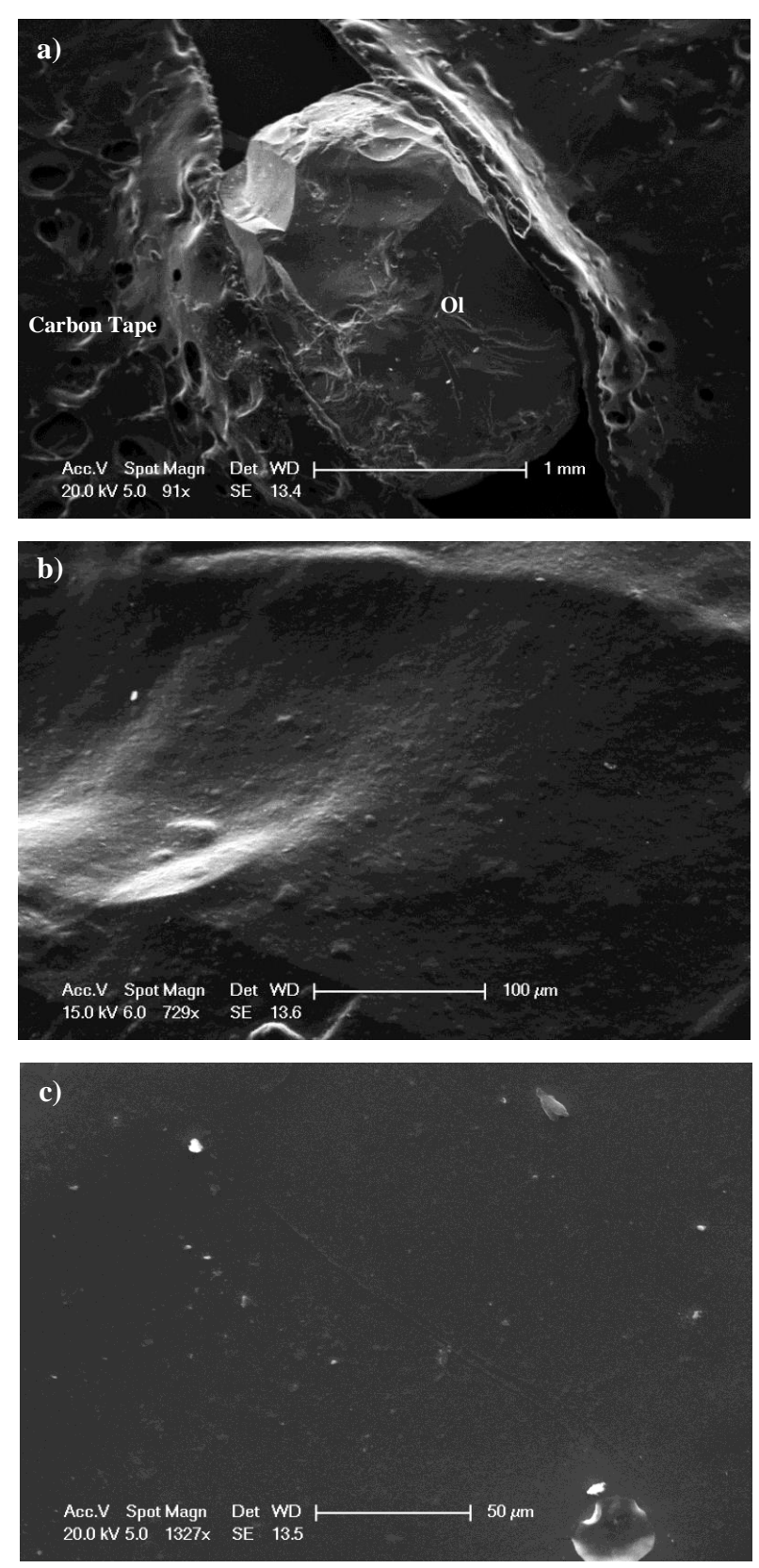

Figure 5. SEM imagery for an olivine phenocryst from an Icelandic picritic basalt lava. (a) Olivine grain bounded by mounting tape showing overall morphology of crystal grown from melt. $(\mathbf{b}+\mathbf{c})$ Detailed images of primary surfaces (unfractured) typical of phenocrystic olivine which shows minimal topography.

\section{Results}

\subsection{Image analysis results}

The cumulative frequency plot (Fig. 4b) shows the sphereequivalent grain size plotted as a function of cumulative area percent. We have computed the Inman graphical standard de- viation $\left(\sigma_{\varphi}\right)$ for this 2-D analysis, as defined by

$\sigma_{\varphi}=\left(\varphi_{84}-\varphi_{16}\right) / 2$

to be 0.6 (Inman, 1952). On this basis, the olivine grains are very well sorted in accordance to pyroclastic classification and lie within the very well to moderately sorted descriptor for sedimentary rocks (Cas and Wright, 1987). We also calculated the circularity $(C)$, a measure of roundness, for the olivine grains using

$C=4 \pi\left(A / P_{\text {Trace }}^{2}\right)$,

where $A$ and $P_{\text {Trace }}$ are the area and the perimeter of individual olivine grains recovered by image analysis via ImageJ. A circularity value of 1 indicates a perfect circle, and for all other shapes circularities are $<1$. As the value tends to 0 , an increasingly elongated polygon is formed. Figure $4 \mathrm{c}$ shows a sharp peak in olivine circularity at ca. 0.85 ; nearly all IHV olivine grains show circularity values within a narrow range of 0.7 to 0.95 . This quantifies the highly rounded nature to be well rounded and close to a circle.

Lastly, we define a new parameter of ellipticity $(E)$, by Eq. (3):

$E=P_{R} / P_{\text {Trace }}$,

where $P_{R}$ is the perimeter of a model ellipse which has the same major, $a_{\text {Trace }}$, and minor, $b_{\text {Trace }}$, axes as those measured on the olivine outline. The model ellipse is calculated by the Ramanujan approximation shown in Eq. (4) (Campbell, 2012; Ramanujan, 1962).

$$
\begin{aligned}
& P_{R}=\pi\left(3\left(\frac{a_{\text {Trace }}}{2}+\frac{b_{\text {Trace }}}{2}\right)\right. \\
& -\sqrt{\left.\left(\frac{3 a_{\text {Trace }}}{2}+\frac{b_{\text {Trace }}}{2}\right)\left(\frac{a_{\text {Trace }}}{2}+\frac{3 b_{\text {Trace }}}{2}\right)\right)}
\end{aligned}
$$

Figure $4 \mathrm{~d}$ shows the distribution of ellipticity values for the digitalised slab (Fig. 4a). For this parameter $E=1$ is true for a perfect ellipse, and all other values $<1$ represent other shapes which deviate from a perfect ellipse. The olivine grains have a mean ellipticity of 0.935 , and ca. $97 \%$ of the measured olivine grains have ellipticity values between 0.9 and 1.0. When comparing Fig. $4 \mathrm{c}$ and $\mathrm{d}$ it is clear that the olivine grains are better described in 2-D as an ellipse rather than a circle. Tables of values of circularity and ellipticity can be found in Appendix A.

\subsection{Scanning electron microscopy}

\subsubsection{Phenocrystic olivine}

Samples used for SEM imaging show little evidence of fractured surfaces resulting from the extraction of the crystals from the parent rock. They represent the primary surfaces of 

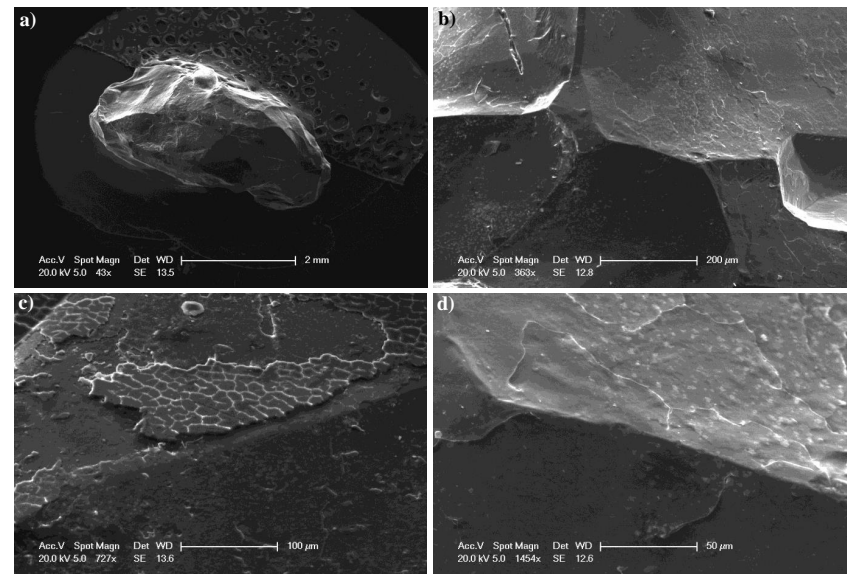

Figure 6. SEM imagery for an olivine grain from mantle-derived peridotite. (a) Olivine grain bounded by mounting tape (top) showing overall shape of grain. (b) Detailed image of primary surface (unfractured) of olivine typical of grains forming an interlocking mosaic within mantle peridotite. (c) Polygonal textured surface flaking. (d) Common small-scale surface flakes on the mantle olivine surface. Higher relief is observed at the edge of the flake, creating a stepped topography.

the olivine crystals which crystallised as a phenocryst phase from the basaltic melt. The overall crystal morphology is shown in Fig. 5a. Figure 5b and 5c show a typical featureless surface at two different magnifications: it is very smooth, and flakes and pits are not present.

\subsubsection{Mantle olivine}

SEM imaging confirms that these samples represent primary olivine surfaces that have not experienced alteration or unnatural fracturing during extraction from the host rock (Fig. 6a). The overall morphology is governed by the interlocking of adjacent mantle olivine crystals within the peridotite forming the observed moulds (Fig. 6b). The mantle olivine is marked by little surface topographic relief despite common flake structures. In some places polygonal flakes are peeling away from the crystal (Fig. 6c and d). A clear topographic difference can be observed between the flaking layer and the smoother olivine surface.

\subsubsection{Igwisi Hills lava olivine}

The distinctive surfaces of the IHV olivine crystals are highly flaked, exfoliated, irregular and rough compared to the phenocrystic and mantle olivine. These irregular surfaces are characterised as a series of meandering ridges and arc-like steps, creating differences in relief. This surface feature is not confined to a small proportion of the sample; rather it occurs over the entire surface of each IHV olivine analysed.

The exterior surfaces of the IHV olivine grains also feature hemispherical impact cavities or pits (Fig. 7b). The interi-
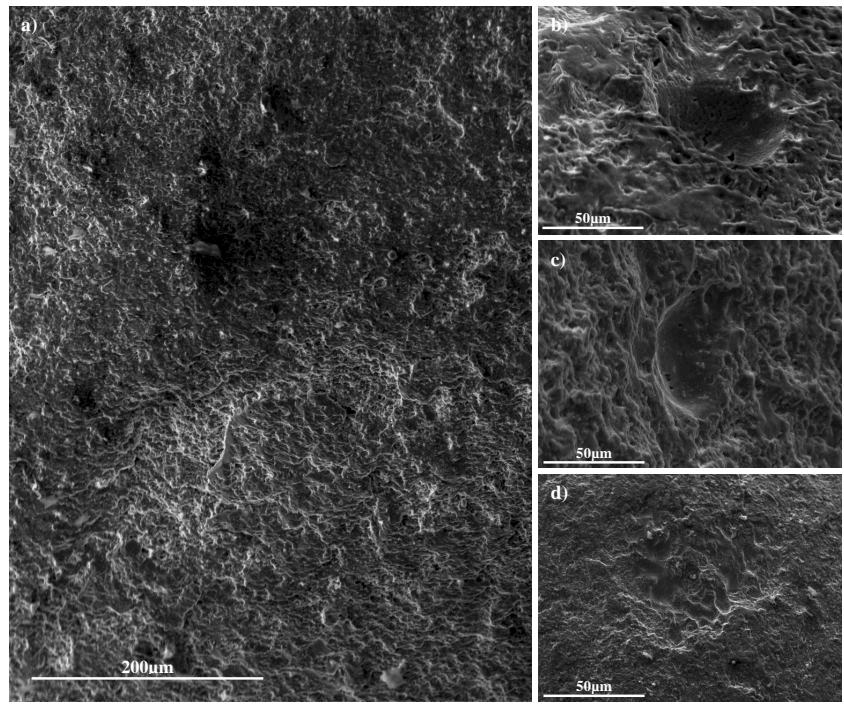

Figure 7. SEM imagery for Igwisi Hills lava olivine. (a) Largescale image showing distinctive surface texture. (b) Hemispherical impact cavity featuring a smooth interior. (c) A common semihemispherical impact pit, again having a smooth interior. (d) Several semi-hemispherical excavations; the edge of this attrition feature demonstrates penetrative multiple layer flaking of the olivine surface.

ors of the pits are smooth, while the surface surrounding the pits is rough and flaky. The cavities are near-perfect hemispheres, with average diameters of $\sim 5 \mu \mathrm{m}$ superimposed on the flaked surfaces indicating a syn- to post-flaking series of events. Figure $7 \mathrm{c}$ shows a semi-hemispherical cavity, identical to Fig. $7 \mathrm{~b}$ in terms of structure and overprinting relationships, but different in shape. In this image you are also able to observe that layering exists below the surface; the flaking is not just a superficial surface feature and is most likely related to the extensive fracturing observed at the grain edges in thin section (Fig. 3). Figure 7d shows a larger-scale feature, which is dominant on the Igwisi Hills lava olivine surface; it compromises several semi-hemispherical cavities similar to that shown in Fig. 7c. It creates a relatively smooth surface overprinting the irregular flakes and ridges.

\subsubsection{3-D Laser measuring microscopy}

The contour map (Fig. 8a and b) for the phenocrystic olivine reveals a surface with negligible $(\leq 3 \mu \mathrm{m})$ topography relief. Indeed, $98 \%$ of the topography ranges within $\pm 2 \mu \mathrm{m}$ of the median surface. The contour map (Fig. 8c and 8d) for the mantle olivine shows a stepped appearance; all the measured mantle olivine surfaces show a decrease in surface elevation with increasing distance along the $x$ axis. The steps are subparallel to the $y$ axis and generate a decrease in topography of about $15 \mu \mathrm{m}$ across the field of view; it is believed that these steps represent surfaces parallel to crystal faces exposed by 


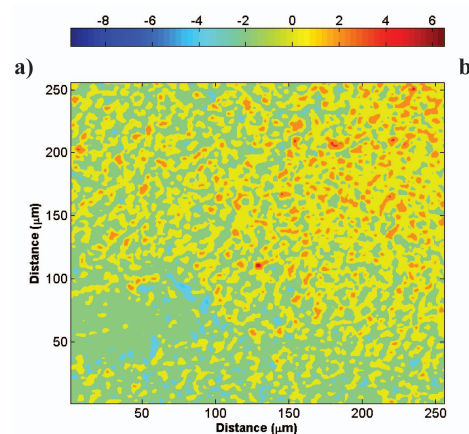

c)

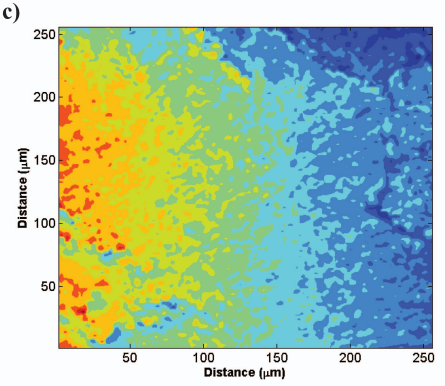

e)

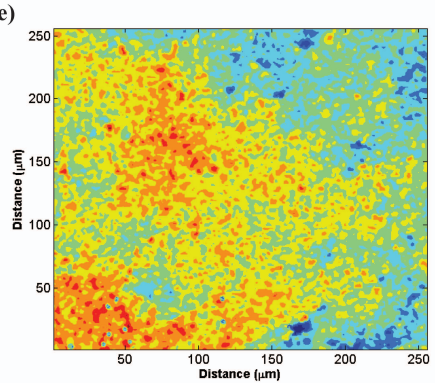

b)
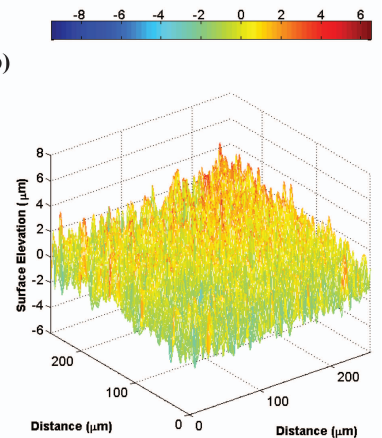

d)

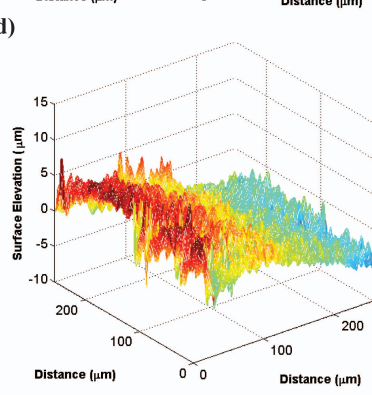

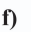

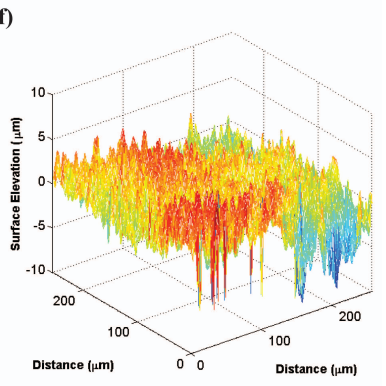

Figure 8. MATLAB-generated contour maps and topographic nets based on data from laser scanning of grain surfaces under microscope. Topographic variations ( $z$ axis) are illustrated by a common colour scale used for all images. Data sets are normalised to the mean topographic elevation; positive $z$ axis values therefore correspond to relief greater than the mean. All maps represent a $256 \mu \mathrm{m}$ by $256 \mu \mathrm{m}$ area on the olivine surface. $(\mathbf{a}+\mathbf{b})$ Phenocrystic olivine, $(\mathbf{c}+\mathbf{d})$ mantle olivine and $(\mathbf{e}+\mathbf{f})$ Igwisi Hills lava olivine.

minor flaking of the olivine crystals exterior (cf. SEM images in Fig. 6).

The IHV samples have a greater surface roughness than both the phenocrystic and mantle olivine grains (Fig. 8f). Contour maps for the IHV olivine (Fig. 8e) also record circular depressions of variable diameter; these are interpreted as the craters/pits observed under the SEM (Fig. 7c). The features are approximately $8-9 \mu \mathrm{m}$ in depth with diameters of $\sim 10-25 \mu \mathrm{m}$.

\section{Discussion}

\subsection{Origin of IHV olivine surface features}

Samples of phenocrystic olivine show smooth, nearly featureless surfaces with zero topography. These surfaces are attributed to free growth from a melt. They show no similarities to the Igwisi Hills samples. Mantle olivine samples commonly display flaked surfaces and a stepped topography (Fig. 6c). However, at a larger scale the mantle olivine grains have sharply faceted, sub-hedral to euhedal shapes, reflecting their textural equilibrium developed under the stable mantle high pressure-temperature conditions of formation. The micron-scale flaking is developed on, and post-dates, these sharply faceted crystal faces. These flaking structures are inferred to form during decompression when the crystal experiences lower pressures during ascent. EDS shows that flakes are identical in chemistry to that of the surrounding fresh olivine (Fig. 6c). Therefore, they are related to decompression rather than to chemical reaction between the crystal and the melt. For example, there is no evidence of melt infiltration and reaction during transport within the mantle nodules (Peterson, 2010).

The olivine grains in the IHV lava display shapes and surface morphologies which are significantly different from features characterising olivine phenocrysts and olivine in mantle peridotite. We observe a highly flaked, irregular and rough surface. The flaky texture parallels the exterior surface but is not just a superficial surface feature. Rather it is penetrative, in that it extends beneath the immediate exterior surface of the olivine grains (Figs. 7a and 3). The flaking structure has some similarities to the flaking observed in the mantle olivine but is much more intense and forms multiple layers. In the IH lava samples the flaking is pervasive, affecting every olivine we analysed.

We interpret the penetrative flaking found on the IH olivines to be related to rapid decompression of the olivine grains during ascent of the kimberlite magma. Olivine is incorporated into kimberlitic magmas at great depths as peridotitic xenoliths. Rapid ascent of $1-20 \mathrm{~m} \mathrm{~s}^{-1}$ (Sparks et al., 2006) of the kimberlite causes pronounced drops in pressure resulting in decompression at rates that can only be accommodated by brittle disaggregation of the xenoliths, liberating olivine grains (Brett, 2009). Tensile failure occurs when the change in stress, coupled to ascent rate, experienced by the olivine crystal is greater than it can viscously relax, defining the tensile strength for kimberlite olivine (Brett, 2009).

High rates of decompression due to rapid ascent rates can cause a rise in tensile stresses at rates faster than can be relaxed viscously. We suggest, therefore, that the flaky exfoliation surfaces on the olivine xenocrysts (Figs. 7 and 3b) are a result of the outer surfaces of the crystal experiencing a build-up of differential (tensile) stress at rates faster than the timescales needed for viscous relaxation. Rapid decompression of solids can cause differential expansion of the clast 


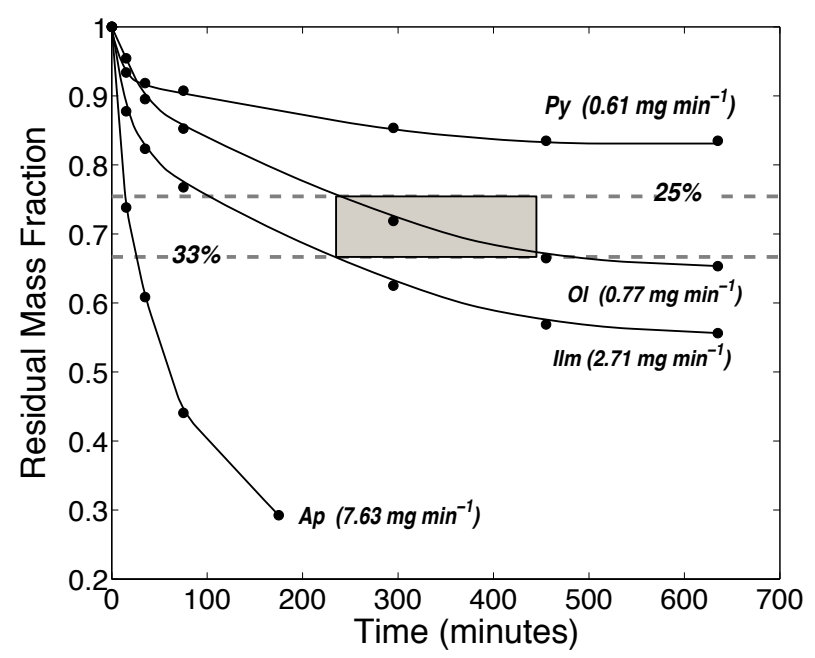

Figure 9. Experimentally measured mass loss rates for four common kimberlitic mineral phases (after Afanas'ev et al., 2008). Residual mass fractions of minerals pyrope (Py), picroilmenites (Ilm), olivine (Ol), and apatite (Ap) being abraded experimentally are plotted against duration (e.g. time). The slopes to the curves define the instantaneous mass loss rates; also shown are the average mass loss rates for each phase $\left(\mathrm{mg} \mathrm{min}^{-1}\right)$. The grey box denotes the estimated mass loss for Igwisi Hills olivines based on their shape (e.g. smoothness, roundness) relative to the calibrated photographs of Afanas'ev et al. (2008).

rim versus its interior. This produces tangential compression within the exterior rim (Fig. 3b) and radial tension in the interior (Preston and White, 1934). We hypothesise that the stresses are partially released by exfoliation of the surface in a similar manner to thermal exfoliation (Preston and White, 1934; Thirumalai, 1969). These partial spalls would be easily removed via crystal-crystal collisions and abrasion during turbulent transport, thereby enhancing the overall rates of attrition (Campbell et al., 2013).

The recrystallisation of strained xenocrystic olivine is commonly localised at the exterior margins of the xenocrysts to create a finer-grained rim of neoblasts (Fig. $3 \mathrm{c}$ and d). This process may also facilitate mechanical milling and attrition of the olivine macrocrysts by plucking of the individual neoblasts. This idea was briefly mentioned by Dawson (1994), who suggested that these plucked recrystallised rims may contribute to the "groundmass" olivine population within the IH lavas.

When comparing IHV olivine surfaces to an experimental abrasion study on kimberlitic garnets (McCandless, 1990), great similarities in surface features are observed (Fig. 2d; McCandless, 1990). These have also been interpreted to form through an abrasion process. We also compare IHV olivine morphologies to another experimental study which compares the relative mass loss of kimberlitic minerals with increased abrasion time (Afanas'ev et al., 2008). When comparing observed morphologies to this experimental data set, we esti- mate IHV olivines are comparable to those subject to 220 455 minutes of abrasion. Then, using a calculated mass loss rate of $0.77 \mathrm{mg} \mathrm{min}^{-1}$, we suggest that the IHV olivine lost $\sim 25-33 \%$ of its original mass during ascent (Fig. 9). These experiments are not thought to exactly replicate the process which we describe; they simply provide first-order estimates of mass loss.

Additionally the surfaces of the IHV olivine grains also feature discrete (semi-)hemispherical cavities or depressions (Fig. $7 \mathrm{~b}$ and c) superimposed on the abrasion surface. We interpret these as impact pits produced by particleparticle collisions, involving higher energies than driving the more steady-state abrasion processes (Campbell et al., 2013; Dufek et al., 2012, 2009).

\subsection{Mechanical versus chemical shaping}

Olivine is well known to chemically react with or dissolve in kimberlitic melt during transport (e.g. Donaldson, 1990; Edwards and Russell, 1996, 1998). We therefore question to what extent the IHV olivine crystals have been modified by chemical processes rather than the mechanical processes described in this study. To investigate this, IHV olivine crystals were etched with $10 \%$ hydrochloric acid on timescales varying from minutes to days. Their surfaces were then analysed under the SEM and compared to the natural samples.

Etch-pit formation by chemical dissolution is affected by the composition of the etchant, the crystal chemistry, crystallographic orientation, and the presence of impurities ("poisons") in the etchant. This poison may enhance the selectivity of the etching surface (Wegner and Christie, 1974). Thus, our experiments are not intended to replicate exactly magmatic dissolution processes; rather they serve as an analogue for comparative purposes.

Figure 10a shows an experimentally etched Igwisi Hills lava olivine; at this scale it resembles all other IH olivine in the sample suite displaying numerous characteristic features shown in Fig. 7. However at higher magnifications (Fig. 10b) previously unidentified features become apparent on the olivine surface. The etched olivine shows elongate structures strongly controlled by the crystallographic structure of the olivine (Fig. 10c); they do not resemble anything observed in the natural samples. Away from the main etch pit the original olivine surface has also been modified and is now more porous and exhibits a honeycomb-like texture; the natural surfaces of IHV olivine grains do not exhibit these textures.

We expect olivine to be subjected to both chemical and mechanical processes during transport. However the shapes and surfaces recorded within the erupted products studied are clearly dominated by mechanical processes; no similarities with the artificially etched samples are identified. We hypothesise that the chemical processes may dominate at greater depth (in the mantle lithosphere). Then, as the magma exsolves fluids and becomes more buoyant, its ascent velocity 

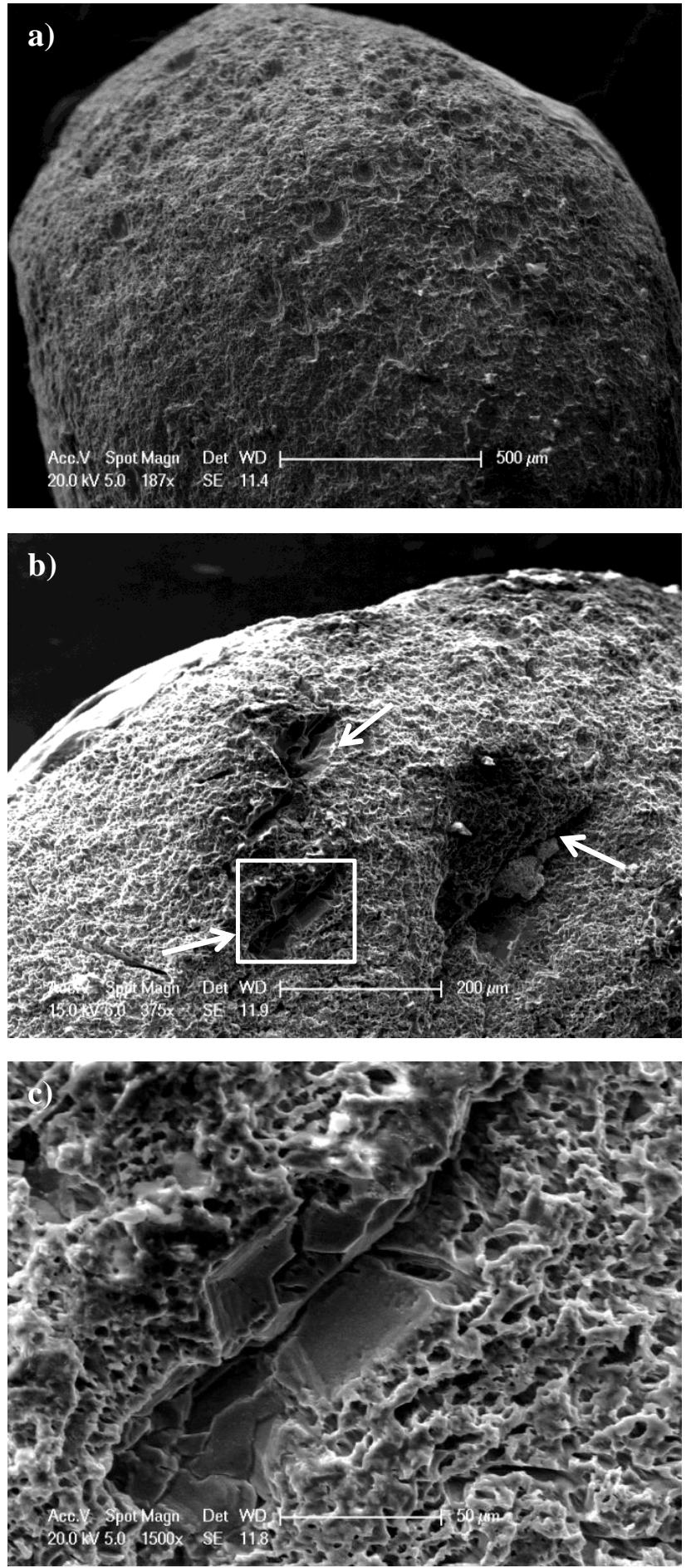

Figure 10. SEM imagery of olivine surfaces subjected to dissolution by weak acids (see text). (a) Overall morphology of etched grain. (b) Detailed image of etched olivine surface; white arrows highlight etch pits. The white box shows the area represented by part (c). (c) An etch pit developed on original surface of Igwisi Hills olivine; dissolution pit shape is strongly controlled by the crystallographic structure of the olivine.

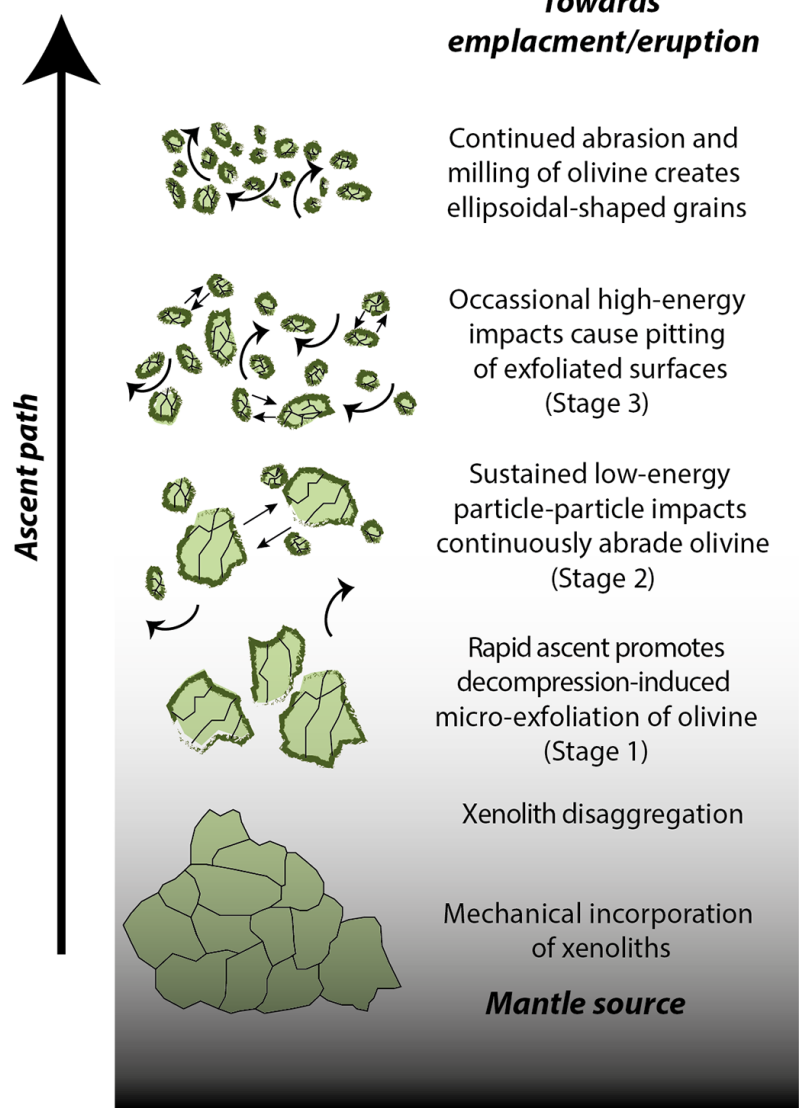

Figure 11. Summary model for the evolution of olivine during ascent of kimberlite. Kimberlite ascent processes cause brittle deformation of mantle peridotite, leading to production and entrainment of mantle xenoliths. Peridotitic xenoliths undergo mechanical disaggregation due to particle-particle collisions and decompression. The decompression is driven by rapid ascent and promotes tensile failure in liberated olivine crystals and is expressed as surface parallel micro-exfoliation. High-velocity (i.e. turbulent) transport of olivine in a solids-rich melt-gas mixture of kimberlite magma supports continual high-frequency low-energy impacts between particles, leading to abrasion and rounding of olivine grains. Periodic higher-energy impacts create impact pits on the olivine's exfoliated microsurfaces. The combination of these processes results in a high proportion of ellipsoidal-shaped, abraded and decompressed olivine grains within the IH lavas.

will rise. This results in a gas-rich mixture travelling at velocities that support turbulent flow and in which mechanical processes begin to dominate.

\subsection{Implications for kimberlite ascent}

Olivines from IHV lavas have elliptical morphologies and surfaces which preserve impact features that, to our knowledge, are unique to kimberlitic systems. Importantly, these features must be the result of magma transport processes, because these olivine samples derive from a pāhoehoe lava re- 
sulting from a quiescent effusion of kimberlite. We propose a three-part model to explain the distinctive attributes of the IHV olivine grains (Fig. 11). Firstly, olivine crystals become incorporated into a kimberlitic melt as whole rock mantle xenoliths. These xenoliths then undergo disaggregation facilitated by mineral expansion during ascent-driven continuous decompression. This imposes a build-up of internal stresses within the olivine crystal. The imposed timescales of ascent are faster than the olivine can viscously relax, and the stresses are relieved by surface parallel micro-exfoliation (Brett, 2009), resulting in the flaked surfaces (Fig. 7a) and intensely fractured olivine rims observed (Fig. 3b).

Secondly, intense decompression of the olivine exterior (Figures $7 \mathrm{a}$ and $3 \mathrm{~b}$ ) makes this xenocrystic cargo more susceptible for abrasion through particle-particle collisions sustained within a rapidly ascending, volatile-rich, turbulent mixture of solid, gas and melt driven by the assimilation of orthopyroxene (Russell et al., 2012). This gives rise to the final highly elliptical, near-spherical morphologies that have been documented. The hypothesis of abrasion producing rounding of angular clasts to spherical shapes is supported by experimental studies (Kuenen, 1960). Abrasion will exploit pre-existing weaknesses and preferentially erode weaker compounds (Suzuki and Takahashi, 1981).

Thirdly, higher-energy particle-particle impacts create the hemispherical and semi-hemispherical impact pits (Fig. 7b and c) that are superimposed on the rounded and exfoliated olivine. These events are of lower frequency and only occur when olivine grains collide at high velocities. However, there is an upper limit to the collisional energy - they must be lower than the threshold required for crystal breakage/disruptive fragmentation (Dufek et al., 2012).

The textures on the olivine grains at the Igwisi Hills volcanoes are unique to kimberlites; to our knowledge there is only one other study, Brett (2009), where similar textures and rounding have been briefly described. The features have not been observed on crystals from other mafic eruptions. This may result from the slower ascent rates and shallower melt sources $(60-80 \mathrm{~km})$ of other mafic volcanic systems (e.g. basalt, basanite, nephelinite), which lead to lower rates of decompression and the build-up of lower tensile stresses within crystals during transport. Additionally, these magmas in general have lower average solid-particle abundances, which reduces the frequency of particle interactions within a turbulent fluid. Lastly, the lower volatile component of non-kimberlitic magmas may result in more viscous magmas that dampen the energy of colliding solid particles.

Xenoliths and xenocrysts of minerals other than olivine are rare within the IHV rocks. This can be explained by the high abrasion stability of olivine (Fig. 9), which is third only to diamond and pyrope (in decreasing order: diamondpyrope-olivine-picroilmenite-apatite-kimberlite; Afanas'ev et al., 2008). Therefore, during rapid turbulent ascent other mantle mineral phases are less likely to survive, relative to olivine.
The observations presented here pertain to the surface features of kimberlitic olivine after transport and eruption. Our model for the mechanical shaping of olivine xenocrysts during kimberlite ascent refines many of the ideas advanced previously in the literature (Table 1). Observations by Brett et al. (2009) suggest a milled xenocrystic core then subsequent crystallisation with or without further milling. Studies by Arndt et al. (2010) propose olivine rim crystallisation followed by abrasion with the removal of Fe-rich regions. We suggest either a continuous milling process occurring throughout xenocrystic transport and subsequent olivine rim crystallisation or repeated cycles of milling and olivine crystallisation during kimberlitic ascent. Both methods would leave rounded xenocrystic cores frequently observed in the literature and surface textures observed in this study.

\section{Conclusions}

The shapes and surface textures of xenocrystic olivine grains extracted from a young kimberlite lava have been described and interpreted. The xenocrystic olivine grains are ellipsoidal, exhibit rough flaky microsurfaces, covered with impact pits. These surface features differ significantly from both olivine phenocrysts and from olivine disaggregated from mantle nodules in the laboratory. A three-part model is proposed to explain these differences. (1) During rapid $\mathrm{CO}_{2}$-driven magma ascent, decompression results in parallel micro-exfoliation on the surface of the xenocrystic olivine grains. (2) Turbulent suspension of solid, gas and melt phases during ascent promotes abrasion that results in the highly elliptical and sub-spherical grain morphology. (3) High-velocity particle-particle impacts result in impact pitting of the surface. Synthetic experiments rule out chemical dissolution and melt reabsorption as the causative process for rounding. The morphology and surface features of the xenocrystic olivine grains are consistent with mechanical processes operating during rapid $\mathrm{CO}_{2}$-driven turbulent ascent of the magma from depth.

\section{The Supplement related to this article is available online at doi:10.5194/se-5-313-2014-supplement.}

Acknowledgements. We thank AMPEL for support with the Laser Measuring Microscope. J. K. Russell is supported by the NSERC Discovery Grants programme. L. A. Porritt acknowledges support from a Marie Curie International Outgoing Postdoctoral Fellowship. Fieldwork on the Igwisi Hills Volcanoes was supported by a grant from National Geographic Committee for Research and Exploration awarded to R. J. Brown. We gratefully acknowledge critical reviews by Nicholas Arndt and an anonymous reviewer. We also thank Mike Heap for his editorial role.

Edited by: M. Heap 


\section{References}

Afanas'ev, V. P., Nikolenko, E. I., Tychkov, N. S., Titov, A. T., Tolstov, A. V., Kornilova, V. P., and Sobolev, N. V.: Mechanical abrasion of kimberlite indicator minerals: experimental investigations, Russ. Geol. Geophys., 49, 91-97, 2008.

Arndt, N., Boullier, A.-M., Clement, J., Dubois, M., and Schissel, D.: What olivine, the neglected mineral, tells us about kimberlite petrogenesis, eEarth Discuss., 1, 37-50, 2006.

Arndt, N. T., Guitreau, M., Boullier, A.-M., Le Roex, A., Tommasi, A., Cordier, P., and Sobolev, A.: Olivine, and the Origin of Kimberlite, J. Petrol., 51, 573-602, 2010.

Boyd, F.: Garnet peridotites and the system $\mathrm{CaSiO} 3-\mathrm{MgSiO} 3-$ $\mathrm{Al}_{2} \mathrm{O}_{3}$, Mineral. Soc. Amer. Spec. Pap, 3, 63-75, 1970.

Brett, R. C.: Kimberlitic olivine: Msc Thesis, University of British Columbia, 2009.

Brett, R., Russell, J., and Moss, S.: Origin of olivine in kimberlite: Phenocryst or impostor?, Lithos, 112, 201-212, 2009.

Brown, R. J., Manya, S., Buisman, I., Fontana, G., Field, M., Mac Niocaill, C., Sparks, R., and Stuart, F.: Eruption of kimberlite magmas: physical volcanology, geomorphology and age of the youngest kimberlitic volcanoes known on earth (the Upper Pleistocene/Holocene Igwisi Hills volcanoes, Tanzania), Bull. Volcan., 74, 1621-1643, 2012.

Campbell, M.: Thermomechanical milling of lithics in volcanic conduits: Msc Thesis, University of British Columbia, 2012.

Campbell, M. E., Russell, J. K., and Porritt, L. A.: Thermomechanical milling of accessory lithics in volcanic conduits, Earth Planet. Sci. Lett., 377/378, 276-286, 2013.

Cas, R. A. and Wright, J. V.: Volcanic successions, modern and ancient: A geological approach to processes, products, and successions, Allen \& Unwin, 1987.

Clement, C. and Skinner, E.: A textural genetic classification of kimberlite rocks. Kimberlite Symposium II, Cambridge, in: Proceedings Extended Abstracts, 1979-1985.

Clement, C. and Skinner, E.: A textural-genetic classification of kimberlites, South Afr. J. Geol., 88, 403-409, 1985.

Davis, B., and Boyd, F.: The join Mg2Si2O6-CaMgSi2O6 at 30 kilobars pressure and its application to pyroxenes from kimberlites, J. Geophys. Res., 71, 3567-3576, 1966,

Dawson, J.: Quaternary kimberlitic volcanism on the Tanzania Craton, Contr. Mineral. Petrol., 116, 473-485, 1994.

Dawson, J. B. and Hawthorne, J. B.: Magmatic sedimentation and carbonatitic differentiation in kimberlite sills at Benfontein, South Africa, J. Geol. Soc., 129, 61-85, 1973.

Donaldson, C.: Forsterite dissolution in superheated basaltic, andesitic and rhyolitic melts, Mineral. Mag., 54, 67-74, 1990.

Dufek, J., Wexler, J., and Manga, M.: Transport capacity of pyroclastic density currents: Experiments and models of substrate-flow interaction, J. Geophys. Res., 114, B11203, doi:10.1029/2008JB006216, 2009.

Dufek, J., Manga, M., and Patel, A.: Granular disruption during explosive volcanic eruptions, Nature Geosci., 5, 561-564, 2012.

Edwards, B. and Russell, J.: A review and analysis of silicate mineral dissolution experiments in natural silicate melts, Chem. Geol., 130, 233-245, 1996.

Edwards, B. R. and Russell, J. K.: Time scales of magmatic processes: new insights from dynamic models for magmatic assimilation, Geology, 26, 1103-1106, 1998.
Field, M., Gernon, T. M., Mock, A., Walters, A., Sparks, R. S. J., and Jerram, D. A.: Variations of olivine abundance and grain size in the Snap Lake kimberlite intrusion, Northwest Territories, Canada: A possible proxy for diamonds, Lithos, 112, 23-35, 2009.

Gernon, T., Field, M., and Sparks, R.: Geology of the Snap Lake kimberlite intrusion, Northwest Territories, Canada: field observations and their interpretation, J. Geol. Soc., 169, 1-16, 2012.

Inman, D. L.: Measures for describing the size distribution of sediments,: J. Sediment. Res., 22, 125-145, 1952.

Jerram, D. A., Mock, A., Davis, G. R., Field, M., and Brown, R. J.: 3D crystal size distributions: A case study on quantifying olivine populations in kimberlites, Lithos, 112, 223-235, 2009.

Kamenetsky, V. S., Kamenetsky, M. B., Sobolev, A. V., Golovin, A. V., Demouchy, S., Faure, K., Sharygin, V. V., and Kuzmin, D. V.: Olivine in the Udachnaya-East kimberlite (Yakutia, Russia): types, compositions and origins, J. Petrol., 49, 823-839, 2008.

Kuenen, P. H.: Experimental Abrasion 4: Eolian Action: J. Geology, 68, 427-449, 1960.

McCandless, T. E.: Kimberlite xenocryst wear in high-energy fluvial systems: experimental studies, J. Geochem. Explor., 37, 323-331, 1990.

Mitchell, R.: Kimberlite and Related Rocks: A Critical Reappraisal, J. Geol., 78, 686-704, 1970.

Mitchell, R. H.: Kimberlites: mineralogy, geochemistry, and petrology, Plenum Press New York, 1986.

Mitchell, R. H.: Kimberlites, orangeites, and related rocks, Plenum Press New York, 1995.

Mitchell, R. H.: Petrology of hypabyssal kimberlites: relevance to primary magma compositions, J. Volcanol. Geothermal Res., 174, 1-8, 2008.

Moore, A. E.: The case for a cognate, polybaric origin for kimberlitic olivines, Lithos, 128, 1-10, 2012.

Moss, S. and Russell, J. K.: Fragmentation in kimberlite: products and intensity of explosive eruption, Bull. Volcanol., 73, 9831003, 2011.

Moss, S., Russell, J. K., Smith, B. H. S., and Brett, R. C.: Olivine crystal size distributions in kimberlite, Am. Mineral., 95, 527536, 2010.

Peterson, N. D.: Carbonated mantle lithosphere in the western Canadian Cordillera, 2010.

Pilbeam, L. H., Nielsen, T. F. D., and Waight, T. E.: Digestion Fractional Crystallization (DFC): an Important Process in the Genesis of Kimberlites. Evidence from Olivine in the Majuagaa Kimberlite, Southern West Greenland, J. Petrol., 54, 1399-1425, 2013.

Preston, F. W. and White, H. E.: OBSERVATIONS ON SPALLING*, J. Am. Ceram. Soc., 17, 137-144, 1934.

Ramanujan, S.: Ramanujan's collected works: New York: Chelsea, 1962.

Reid, A. M., Donaldson, C., Dawson, J., Brown, R., and Ridley, W.: The Igwisi Hills extrusive "kimberlites", Phys. Chem. Earth, 9, 199-218, 1975.

Russell, J. K., Porritt, L. A., Lavallée, Y., and Dingwell, D. B.: Kimberlite ascent by assimilation-fuelled buoyancy, Nature, 481, 352-356, 2012.

Sparks, R.: Kimberlite Volcanism, Ann. Rev. Earth Planet. Sci., 41, 497-528, 2013. 
Sparks, R., Baker, L., Brown, R., Field, M., Schumacher, J., Stripp, G., and Walters, A.: Dynamical constraints on kimberlite volcanism, J. Volcanol. Geothermal Res., 155, 18-48, 2006.

Suzuki, T. and Takahashi, K. I.: An experimental study of wind abrasion, J. Geol., 89, 509-522, 1981.

Thirumalai, K.: Process Of Thermal Spalling Behavior In Rocks An Exploratory Study, in: Proceedings The 11th US Symposium on Rock Mechanics (USRMS), 1969.
Wegner, M. and Christie, J.: Preferential chemical etching of terrestrial and lunar olivines, Contribut. Mineral. Petrol., 43, 195-212, 1974.

Willcox, A., Buisman, I., Sparks, S., Brown, R., Manya, S., Schumacher, J., and Tuffen, H.: Petrology, geochemistry and lowtemperature alteration of extrusive lavas and pyroclastic rocks of the Igwisi Hills kimberlites, Tanzania, Chem. Geol., in preparation, 2014 